Published December 2019

EKONOMIKAWAN : Jurnal IImu Ekonomi dan Studi Pembangunan

ISSN : 1693-7600 (Print), ISSN : 2598-0157 (Online), http://jurnal.umsu.ac.id/indexphp/ekawan

\title{
Community Development Program Arisan Jamban di Dukuh Sebatang, Desa Hargotirto, Kulonprogo Etik Anjar Fitriarti
}

Program Studi Magister Ilmu Komunikasi, Universitas Gadjah Mada, Yogyakarta, Indonesia Bulaksumur, Caturtunggal, Kec. Depok, Kabupaten Sleman, Yogyakarta 55281 e-mail : etika.fitriarti@gmail.com

\begin{abstract}
ABSTRAK
Dukuh Sebatang sebagai salah satu dukuh yang tercatat memiliki $200 \mathrm{KK}$ (Kepala Keluarga). Dukuh Sebatang dipilih sebagai lokasi pelaksanaan program MI (Menyapa Indonesia) karena dianggap paling membutuhkan bantuan pengembangan masyarakat dibandingkan dukuh lain yang ada di sekitarnya. Hasil survey lapangan tim MI gabungan memperlihatkan bahwa 166 dari 200 KK masih termasuk ke dalam kategori KK prasejahtera. Dalam Upaya membantu meningkatkan kesejahteraan hidup masyarakat di dukuh Sebatang, tim MI Gabungan mencanangkan program pemberdayaan serta pengembangan Dukuh Sebatang yang berorientasi pada empat bidang utama, yaitu bidang kesehatan, ekonomi, pendidikan dan budaya, serta infrastruktur. Penelitian ini ditujukan untuk menjawab bagaimana kegiatan Community Development di bidang Kesehatan oleh Awardee LPDP PK (Persiapan Keberangkatan)-41 bertajuk "Menyapa Indonesia" dalam program Arisan Jamban di dukuh Sebatang, Desa Hargotirto, Kulonprogo? Penelitian ini menggunakan metode deskriptif kualitatif. Penulis mencari informan melalui teknik snow-ball sampling, observasi dan studi dokumentasi sebagai data sekunder. Hasil dari program ini tercapainya target pembangunan jamban. Melalui program Arisan Jamban masyarakat dapat berperan aktif dalam membangun dan memelihara fasilitas kesehatan berupa jamban yang sehat sehingga kualitas kesehatan masyarakat di dukuh Sebatang semakin mengalami perbaikan dan menuju kemandirian.
\end{abstract}

Kata Kunci: Community development, pemberdayaan masyarakat, kesehatan lingkungan, arisan jamban, Menyapa Indonesia. 


\title{
Latrine Community Development Program in Dukuh Sebatang, Hargotirto Village, Kulonprogo
}

\begin{abstract}
Dukuh Sebatang is selected as the locations of the Menyapa Indonesia program. The results of various surveys showed that there were 166 of 200 households still categorized as poor families. To help improve the welfare of people lives in dukuh Sebatang, the team introduced the empowerment and development of dukuh that is oriented to four key areas the health sector, economic, education and culture, and infrastructure. This study aims to said how the community development in the field of health by awardee LPDP PK41. Qualitative descriptive method was used in this study. Researchers looking for informants snow-ball technique, observation and study documentation as secondary data. The result of this program the achievement of the privy development targets. Through the program of arisan jamban the community can play an active role in building and maintaining health facilities in the form of a healthy privy resulting in the public health at the dukuh Sebatang.

Keywords: Community development, health empowerment, arisan jamban,

Menyapa Indonesia.
\end{abstract}

\section{PENDAHULUAN}

Pembangunan yang belum merata di seluruh cakupan wilayah Indonesia merupakan permasalahan yang tidaklah mudah. Adanya ketimpangan dari segi kemajuan dan kemandirian masyarakat mempengaruhi pola kehidupan masyarakat baik dari bidang pendidikan, ekonomi dan juga kesehatan. Pemerataan pembangunan bukan semata-mata tugas pemerintah saja tetapi setiap rakyat Indonesia yang memiliki kemampuan dapat bersama-sama mewujudkan keberdayaan masyarakat khususnya di daerah tertinggal. Pemberdayaan atau pengembangan masyarakat atau disebut community development adalah program bersama masyarakat binaan untuk mencapai suatu kemandirian dari segi pendidikan, ekonomi maupun kesehatan. Berkaitan dengan bidang kesehatan masyarakat di daerah tertinggal, tim awardee LPDP PK (Persiapan Keberangkatan)-41 dalam social project yang bertajuk "Menyapa Indonesia" menggelar aksi community development di dukuh Sebatang yang merupakan bagian dari wilayah kabupaten Kulonprogo.

Program "Menyapa Indonesia" adalah program pengembangan masyarakat yang dijalankan dan dikelola oleh para awardee LPDP sebagai bentuk baktinya kepada negeri. Awardee LPDP merupakan penerima beasiswa dari Kementerian Keuangan Republik Indonesia. Program ini dilakukan bertujuan untuk meningkatkan kualitas hidup masyarakat di beberapa lokasi daerah tertinggal di Indonesia yang masih terbatas dalam mengakses fasilitas pendidikan, teknologi, kesehatan dan sebagainya. Biaya yang digunakan oleh BPILPDP dalam memberikan beasiswa dan program ini bersumber dari dana abadi hasil dari pengumpulan pajak rakyat Indonesia. 


\section{Published December 2019}

EKONOMIKAWAN : Jurnal IImu Ekonomi dan Studi Pembangunan

ISSN : 1693-7600 (Print), ISSN : 2598-0157 (Online), http://jurnal.umsu.ac.id/indexphp/ekawan

Oleh sebab itu, sebelum menempuh perkuliahan di perguruan tinggi masingmasing, para awardee ini diberikan ruang untuk menerapkan pengabdian ke masyarakat melalui program Menyapa Indonesia untuk menunjukkan kepedulian serta jiwa kepemimipinan untuk berbakti pada negara dengan bentuk program pengabdian tersebut.

Dukuh Sebatang tercatat sebagai salah satu dukuh yang memiliki 200 Kepala Keluarga (KK). Dukuh Sebatang dipilih sebagai lokasi penerapan program MI (Menyapa Indonesia) karena dianggap paling membutuhkan bantuan pengembangan masyarakat dibandingkan dukuh lain yang ada di sekitarnya. Hasil survei lapangan tim MI gabungan memperlihatkan bahwa 166 dari 200 KK masih termasuk ke dalam kategori KK prasejahtera. Tim MI melaksanakan program pemberdayaan serta pengembangan dukuh Sebatang yang berorientasi pada empat bidang utama, yaitu bidang kesehatan, ekonomi, pendidikan dan budaya, serta infrastruktur sebagai upaya membantu meningkatkan kesejahteraan hidup masyarakat di dukuh Sebatang. Permasalahan yang ada di dukuh Sebatang terutama di bidang kesehatan yaitu penyakit degeneratif serta ISPA (infeksi saluran nafas atas) yang masih diderita beberapa masyarakat. Selain itu fasilitas sanitasi berupa mandi cuci kakus (MCK), akses air bersih serta sarana pelayanan kesehatan yang masih minim. Beberapa rumah-rumah warga juga dinilai belum memenuhi kriteria rumah sehat.

Project Leader MI PK-41 mengatakan lokasi geografis dukuh Sebatang berada di daerah pegunungan yang pada saat itu kondisi infrastruktur berupa jalan yang belum memadai sehingga warga sulit dalam mengakses fasilitas publik terutama fasilitas kesehatan. Ketika ada warga yang sakit dan ingin berobat mereka harus menunggu puskesmas keliling yang biasanya datang hanya sebulan sekali ke dukuh Sebatang. Selain itu ada faktor lain yang menjadi pengaruh masih kurangnya perhatian dan pemahaman masyarakat terhadap penyakit sebab mayoritas masyarakat setempat memiliki tingkat pendidikan yang relatif rendah. Oleh karena itu sebagai bentuk upaya dalam mengakomodasi kondisi-kondisi masyarakat tersebut, awardee PK-41 mengembangkan tiga program kesehatan di dukuh Sebatang, yaitu pembentukan kader penyuluh kesehatan, arisan jamban, dan kajian air bersih.

Tingkat kemiskinan di kecamatan Kokap, kabupaten Kulonprogo, Daerah Istimewa Yogyakarta (DIY) saat itu mencapai 23,38\% dengan ketimpangan sosial masyarakat yang cukup besar. Seperti yang telah disebutkan sebelumnya, jika dilihat dari segi kesehatan, dukuh Sebatang ini memiliki beberapa permasalahan, masih ada masyarakat yang terjangkit penyakit degeneratif dan ISPA, fasilitas mandi cuci kakus (MCK) yang masih kurang memadai, akses air bersih yang masih sulit, kurangnya sarana pelayanan kesehatan, dan juga terdapat banyak rumah warga yang belum masuk kriteria rumah sehat. Berdasarkan keterangan dari bapak Sumijan selaku Kepala Desa Dukuh Sebatang, Desa Hargotirto, Kecamatan Kokap, tingkat kemiskinan warga tersebut mengakibatkan sebanyak 56 Kepala Keluarga sampai saat ini tidak memiliki jamban yang sehat. Berdasarkan keterangan dari warga dukuh Sebatang hal tersebut dikarenakan keterbatasan dana, hingga mereka belum pernah memiliki jamban yang layak. Oleh karena itu mereka belum memiliki jamban yang sesuai dengan kriteria jamban sehat, maka mereka menggunakan jamban cemplung di sekitar rumah mereka. Adapun rumusan dari pengabdian masyarakat ini adalah bagaimana kegiatan community development program arisan jamban di dukuh Sebatang, Desa Hargotirto, Kokap, Kulonprogo ? 


\section{KAJIAN TEORI}

Rhonda Phillips dan Robert H. Pittman memberikan definisi community development dalam bukunya An Introduction to Community Development (2008 : 6) bahwa community development fokus pada proses untuk mendidik atau mengajarkan masyarakat agar mampu bekerja sama dalam memecahkan serta mengatasi permasalahan sosial. Menurut Zubaedi dalam bukunya Pengembangan Masyarakat ; Wacana dan Praktik ( 2013 : 6), merujuk pendapat Gordon G. Darkenwald dan Sharan B. Meriam bahwa pokok dari community development yaitu kegiatan sosial yang bertujuan untuk mengatasi permasalahan sosial di masyarakat.

Menurut Susanto (dalam Rahman, 2009:34) program community development dapat dilakukan dengan alur pengembangan dan situasi serta kondisi masyarakat dengan berpijak pada prinsip pengembangan konsep, tujuan, dan sasaran program berdasar dari analisa kebutuhan masyarakat atau community need analysis. Terkait dengan analisa kebutuhan masyarakat, perusahaan atau lembaga yang melakukan community development seharusnya mampu mngetahui dan mengerti hal-hal yang menjadi kebutuhan masyarakat yang bersifat jangka panjang dan berkelanjutan. Dalam penerapannya analisis kebutuhan masyarakat ini perlu melibatkan berbagai tokoh masyarakat setempat serta orang-orang yang dianggap berpengaruh di lingkungan masyarakat agar dapat mengumpulkan ide-ide program yang menjadi kebutuhan dasar atau keberdasara kepentingan masyarakat bukan hanya kepentingan pihak-pihak tertentu saja.

Kemudian juga dikatakan menurut Budimanta community development adalah program yang berisi kegiatan yang bertujuan untuk pengembangan masyarakat yang diselenggarakan dengan perencanaan, terstrukur atau sistematis serta berorientasi untuk mencapai kehidupan yang lebih berkualitas dari segi kondisi sosial maupun ekonomi dengan memperlebar akses masyarakat dalam menuju orientasi kesejahteraan tersebut (dalam Rahman, 2009:108). Pokok dari community development ini adalah upaya pemberdayaan masyarakat yang merupakan hasil kolaborasi dari lembaga atau perusahaan terkait, pemerintah serta masyarakat atau komunitas setempat.

Setelah melakukan analisis kebutuhan masyarakat, tahap selanjutnya yaitu sosialisasi program kepada masyarakat setempat yang terlibat dalam program. Hal ini dilakukan dengan tujuan agar masyarakat yang menjadi target program dapat terlibat dan berperan aktif dalam kegiatan tersebut sehingga muncul rasa memiliki dan tanggung jawab terhadap program yang dilakukan di wilayahnya sehingga dapat mempermudah tercapainya target program. Proses sosialisasi ini merupakan aktivitas komunikasi persuasif kepada masyarakat yang menggunakan berbagai macam media komunikasi kepada masyarakat. Sosialisasi ini bertujuan untuk meningkatkan partisipasi masyarakat. Jim Ife dan Frank Tesoriero mengungkapkan bahwa partisipasi masyarakat ini sebagai suatu konsep pokok dan prinsip dasar dalam community development. Jelaslah dikatakan bahwa partisipasi masyarakat ini merupakan aspek penting dalam kegiatan pemberdayaan yang melibatkan komunitas atau masyarakat. (Jim Ife, 2009:294). 
Published December 2019

EKONOMIKAWAN : Jurnal IImu Ekonomi dan Studi Pembangunan

ISSN : 1693-7600 (Print), ISSN : 2598-0157 (Online), http://jurnal.umsu.ac.id/indexphp/kkawan

\section{METODE}

Penelitian ini menggunakan metode kualitatif dengan jenis penelitian studi deskriptif. Studi deskriptif merupakan penjelasan suatu situasi atau peristiwa (Ruslan, 2006 : 72). Peneliti melakukan penelitian di lapangan dengan metode wawancara dan observasi terhadap fenomena yang dikaji dengan turun langsung ke lokasi penelitian. Observasi lapangan juga dilakukan di dukuh Sebatang, Kulonprogo Yogyakarta untuk mencatat dan menemukan data mengenai program community development pada program arisan jamban. Subjek penelitian ini yaitu awardee LPDP sebagai pelaksana community development di dukuh Sebatang ini. Kriteria informan dari penelitian ini yaitu orang-orang yang memiliki kompetensi, mengetahui dan melaksanakan community development program arisan jamban yang akan diteliti pada penelitian ini. Objek penelitian ini yaitu program community development program arisan jamban di dukuh Sebatang oleh tim Menyapa Indonesia.

Terkait sumber data penelitian ini diperoleh dari hasil wawancara terhadap informan, dan temuan data dari hasil observasi di lapangan dengan melihat secara langsung aktivitas yang dilakukan oleh awardee terhadap masyarakat dukuh Sebatang. Selain itu peneliti juga menggunakan data yang diperoleh dari studi pustaka, seperti jurnal, data di media cetak maupun di internet serta arsip yang relevan untuk mendukung data primer. Penulis mencari informan melalui teknik snow-ball sampling dengan informan potensial terkait penelitian ini kemudian penulis meminta sejumlah informan yang mereka kenal untuk menjadi informan selanjutnya. Melalui informasi dari informan-informan sebelumnya maka peneliti dapat menemukan informan lagi. Begitu seterusnya. (Mulyana, 2010 : 187 188).

\section{Kerangka Pemikiran}

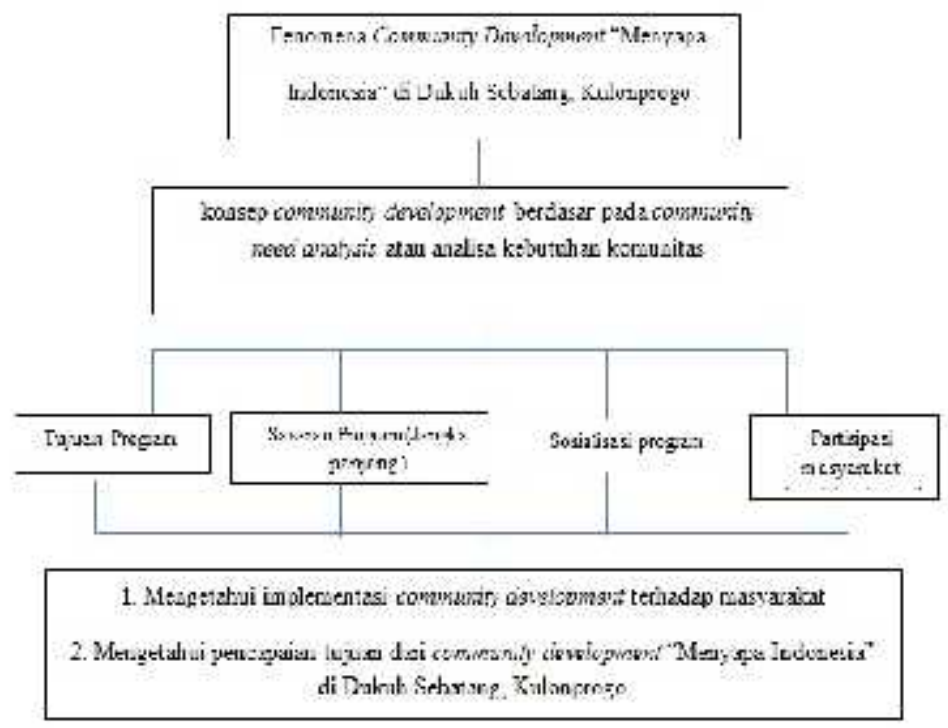

Sumber : Olahan Penulis

Gambar 1. Kerangka Pemikiran 
Published December 2019

EKONOMIKAWAN : Jurnal IImu Ekonomi dan Studi Pembangunan

ISSN : 1693-7600 (Print), ISSN : 2598-0157 (Online), http://jurnal.umsu.ac.id/indexphp/ekawan

\section{HASIL DAN PEMBAHASAN}

Arisan jamban merupakan bentuk community development atau pemberdayaan masyarakat dari tim Menyapa Indonesia yaitu awardee LPDP PK-41. Program ini terkait dengan pembangunan 56 jamban dilakukan di dukuh Sebatang, Hargotirto, Kokap, Kulon Progo, Yogyakarta. Arisan tersebut diikuti oleh warga sejak Juli 2015 dengan adanya koordinir di setiap RT (rukun tetangga) dukuh Sebatang. Program arisan ini dilakukan dengan pengumpulan uang warga setempat yang ikut berpartisipasi dalam program ini sebagai dana pelaksanaan pembangunan jamban dan pengumpulan dana dikoordinasikan oleh pengurus di setiap RT dukuh Sebatang.

Adapun tujuan dari kegiatan arisan jamban ini untuk membantu warga memiliki jamban sehat dan ekonomis di dukuh Sebatang. Di dukuh Sebatang pada saat itu sebanyak 56 Kepala Keluarga (KK) hanya menggunakan jamban cemplung. Melalui kegiatan ini pembangunan jamban melibatkan langsung warga dukuh Sebatang dan turut mengajak warga untuk dapat memeliharanya. Harapannya program arisan jamban ini dapat bermuara pada satu tujuan yaitu kualitas kesehatan masyarakat dukuh Sebatang dapat meningkat secara berkelanjutan. Program arisan jamban ini memiliki beberapa indikator keberhasilan di antaranya yaitu: sebanyak 56 rumah (KK) mengikuti kegiatan arisan jamban, sebanyak 56 rumah dapat memiliki jamban sehat pada akhir tahun 2016 dan tidak ada warga BABS (Buang Air Besar Sembarangan) lagi di tahun 2017.

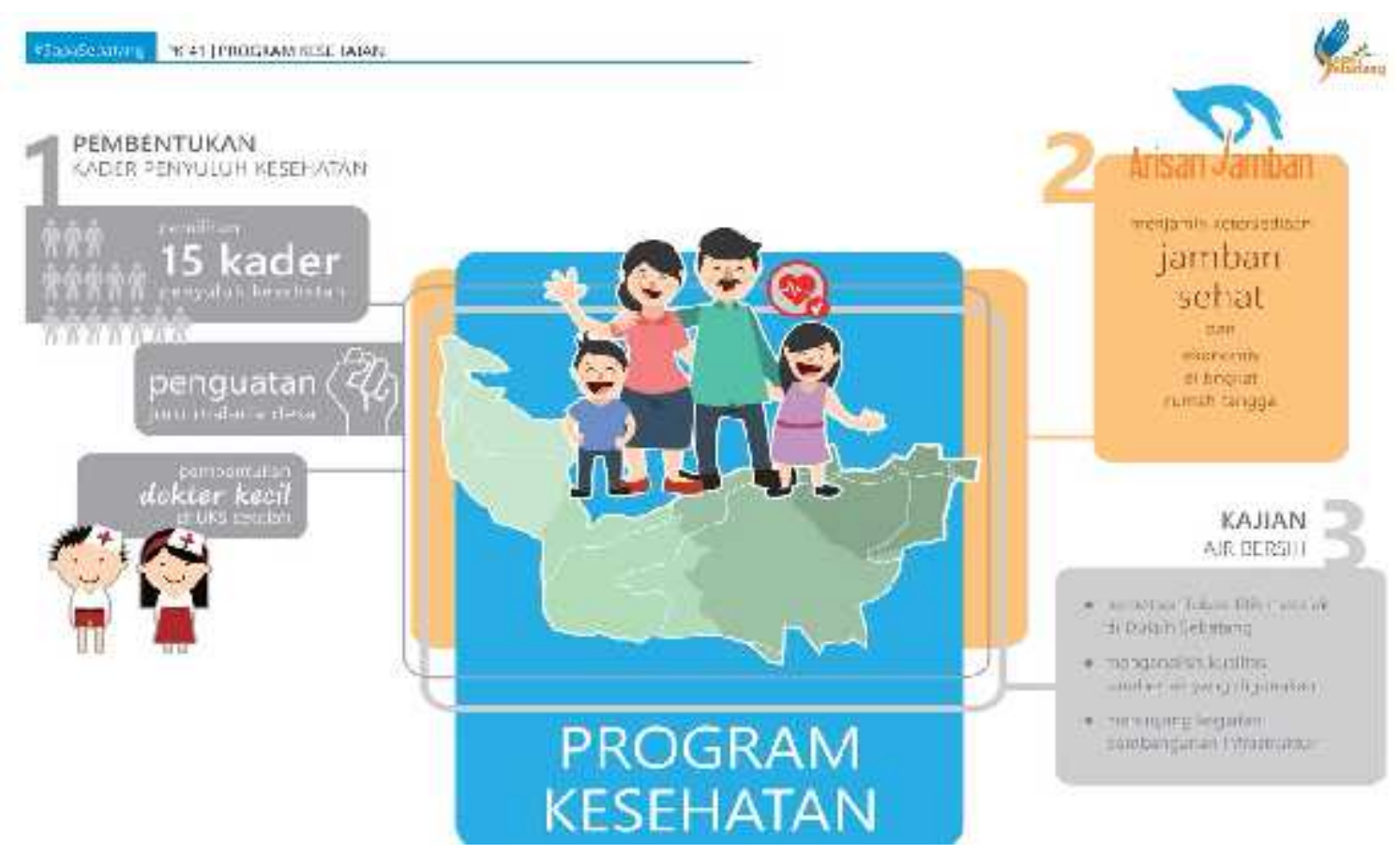

Sumber : https://twitter.com/sapasebatang/status/629617746087559168

(diakses pada 10 Oktober 2019)

Gambar 2. Program Kesehatan Menyapa Indonesia PK-41 
Di dukuh Sebatang terjadi permasalahan sosial terutama di bidang kesehatan berupa sanitasi terutama ketika masyarakat buang air besar sembarangan di jamban cemplung. Hal tersebut masih menjadi kebiasaan masyarakat buang air besar di jamban cemplung yaitu jamban yang dinilai tidak sehat sebab tidak memenuhi persyaratan jamban yang sehat. Jamban cemplung dapat menimbulkan berbagai masalah kesehatan karena hanya dibuat dari suatu lubang di tanah dan kemudian ditutup dengan kayu dan rawan dihinggapi oleh hewan-hewan pembawa penyakit. Di dukuh sebatang sebelum adanya program community development oleh tim Menyapa Indonesia (MI) masih terdapat 56 kepala keluarga yang menggunakan jamban cemplung maka awardee LPDP PK-41 memilih program arisan jamban untuk mengentaskan permasalahan tersebut.

Rhonda Phillips dan Robert H. Pittman memberikan definisi community development dalam bukunya An Introduction to Community Development (2008 : 6) bahwa community development fokus pada proses untuk mendidik atau mengajarkan masyarakat agar mampu bekerja sama dalam memecahkan serta mengatasi permasalahan sosial. Community development adalah program yang berisi kegiatan yang bertujuan untuk pengembangan masyarakat yang dilaksanakan dengan perencanaan, terstrukur atau sistematis serta berorientasi untuk mencapai kehidupan yang lebih berkualitas dari segi kondisi sosial maupun ekonomi dengan memperlebar akses masyarakat dalam menuju orientasi kesejahteraan tersebut (Rahman, 2009:108). Pokok dari community development ini adalah upaya pemberdayaan masyarakat yang merupakan hasil kolaborasi dari lembaga terkait, pemerintah serta masyarakat atau komunitas setempat.

Pelaksanaan program community development menurut Susanto (dalam Rahman, 2009:34) dapat dilakukan dengan alur pengembangan dan situasi serta kondisi masyarakat dengan berpijak pada prinsip pengembangan konsep, tujuan, dan sasaran program berdasar dari analisa kebutuhan masyarakat atau community need analysis. Terkait dengan analisa kebutuhan masyarakat, perusahaan atau lembaga yang melakukan community development seharusnya mampu mngetahui dan mengerti hal-hal yang menjadi kebutuhan masyarakat yang bersifat jangka panjang dan berkelanjutan. Dalam penerapannya analisis kebutuhan masyarakat ini perlu melibatkan berbagai tokoh masyarakat setempat serta orang-orang yang dianggap berpengaruh di lingkungan masyarakat agar dapat mengumpulkan ide-ide program yang menjadi kebutuhan dasar atau keberdasaran kepentingan masyarakat bukan hanya kepentingan pihak-pihak tertentu saja.

\section{Analisa Kebutuhan Masyarakat dan Sasaran Program Arisan Jamban}

Analisa kebutuhan komunitas di dukuh Sebatang dirumuskan berdasarkan kebutuhan dari masyoritas masyarakat yang belum mempunyai jamban yang sehat. Analisa kebutuhan ini tidak hanya mewakili segelintir orang saja namun mewakili 56 kepala keluarga di dukuh Sebatang dan program ini juga turut melibatkan tokoh masyarakat maupun tokoh agama di wilayah tersebut. Seperti yang diungkapkan Syafira, project leader program arisan jamban ini bahwa program arisan jamban bertujuan untuk dapat meningkatkan kualitas kesehatan masyarakat dukuh Sebatang. 
Dalam program pengembangan masyarakat perlu adanya sasaran program untuk membentuk kemandirian dan melibatkan partisispasi aktif dari seluruh masyarakat. Hal tersebut demi terciptanya rasa kepemilikan bersama atau sense of belonging terhadap program tersebut. Suatu program yang memiliki sasaran jangka panjang tentulah memerlukan keaktifan dari masyarakat dalam hal memelihara fasilitas yang telah dibentuk pada program pemberdayaan masyarakat tersebut. Seperti halnya di dukuh Sebatang, Sayfira menjelaskan bahwa metode urunan atau arisan warga untuk membuat jamban yang sehat merupakan suatu bentuk metode yang selain meringankan warga dalam mengumpulkan sumber dana dan yang terutama yaitu untuk membentuk rasa memiliki serta tanggung jawab masyarakat tehadap jamban sehat tersebut. "Melalui sistem arisan tersebut, tim Menyapa Indonesia PK-41 ini memiliki tujuan agar program tersebut dapat meringankan beban para warga terutama dari segi dana melalui subsidi untuk pembangunan jamban. Selain itu juga ditujukan untuk membentuk dan membangun kemandirian warga. Tujuan program ini bukan hanya jamban tersebut dibangun kemudian digunakan sehari-hari tetapi dengan sistem urunan atau arisan warga tersebut juga diharapkan dapat membangun rasa kepemilikan dan tanggung jawab warga untuk menjaga kebersihan dan kesehatan jambannya tersebut." (Syafira, 2016).

Program pengembangan masyarakat melalui arisan jamban ini direncanakan akan berlanjut hingga dua tahun kedepan untuk proses monitoring dan evaluasi. Hal ini menurut Syafira sebagai bentuk pemeliharaan jamban sehat dalam jangka panjang dan hasil dari terkumpulnya sumbangan para donatur juga akan disalurkan pada program kesehatan yang lain, "Untuk pemeliharaan jangka panjang, biaya urunan warga yang terkumpul nanti dan dana yang didapat dari donator juga akan disalurkan untuk program kesehatan lain serta proses monitoring dan evaluasi yang akan dilaksanakan oleh Tim Menyapa Indonesia PK41 (Catureka Mandala) 2 tahun ke depan guna memelihara lingkungan hidup sehat di dukuh Sebatang, di antaranya yaitu: Program Kader Penyuluh Kesehatan yang meliputi penyuluh ODF (STOP BABS), ISPA, kesehatan lingkungan dan malaria, serta pengkajian air bersih guna mendukung program pemberdayaan infrastruktur di dukuh Sebatang" (Syafira, 2016).

\section{Sosialisasi}

Kegiatan sosialisasi kepada masyarakat setempat yang terlibat dalam program merupakan hal yang penting untuk dilakukan. Hal tersebut dilakukan dengan tujuan agar masyarakat yang menjadi target program dapat terlibat dan berperan aktif dalam kegiatan tersebut sehingga muncul rasa memiliki dan tanggung jawab terhadap program yang dilakukan di wilayahnya sehingga dapat mempermudah tercapainya target program. Proses sosialisasi ini merupakan aktivitas komunikasi persuasif kepada masyarakat yang menggunakan berbagai macam media komunikasi kepada masyarakat. Sosialisasi ini bertujuan untuk meningkatkan partisipasi masyarakat. Jim Ife dan Frank Tesoriero mengungkapkan bahwa partisipasi masyarakat ini sebagai suatu konsep pokok dan prinsip dasar dalam community development. Jelaslah dikatakan bahwa partisipasi masyarakat ini merupakan aspek penting dalam kegiatan pemberdayaan yang melibatkan komunitas atau masyarakat. 
Sosialisasi pra program arisan jamban ini dilakukan audiensi dengan Bupati Kulonprogo, petugas-petugas Puskesmas, TOGA (tokoh agama) dan TOMA (tokoh masyarakat) dukuh Sebatang. Selain audiensi kepada tokoh-tokoh yang menjadi opinian leader di wilayah tersebut, nantinya juga akan dilakukan monitoring dan evaluasi setiap enam bulan sekali dengan tiga teknik meliputi observasi, program penelitian, wawancara dan angket.

\section{Partisipasi Masyarakat}

Partisipasi masyarakat sebagai suatu konsep pokok dan prinsip dasar dalam community development. Jelaslah dikatakan bahwa partisipasi masyarakat ini merupakan aspek penting dalam kegiatan pemberdayaan yang melibatkan komunitas atau masyarakat. (Jim Ife, 2009:294). Dalam program membangun jamban sehat dan ekonomis bagi warga dukuh Sebatang tersebut, Tim Menyapa Indonesia PK-41 (Catureka Mandala) melakukan aksi pemberdayaan masyarakat atau community development ini melalui program arisan jamban. Arisan ini maksudnya adalah seperti layaknya arisan, warga yang mengikuti kegiatan ini diwajibkan membayar iuran senilai Rp 1.000,- per hari yang ditujukan untuk membangun jamban. Setelah itu dilanjutkan dengan pengundian sebulan sekali agar mendapatkan nama-nama yang terlebih dahulu mendapat giliran untuk pembangunan jamban di rumahnya. Adapun pembangunan jamban ini dibagi menjadi lima kloter dalam masa lima bulan.

Melalui sistem arisan jamban yang telah disepakati tersebut, Tim Menyapa Indonesia PK-41 ini memiliki tujuan agar program tersebut dapat meringankan beban para warga terutama dari segi dana melalui subsidi untuk pembangunan jamban. Selain itu juga ditujukan untuk membentuk dan membangun kemandirian warga. Tujuan program ini bukan hanya jamban tersebut dibangun kemudian digunakan sehari-hari tetapi dengan sistem urunan atau arisan warga tersebut juga diharapkan dapat membangun rasa kepemilikan dan tanggung jawab warga untuk menjaga kebersihan dan kesehatan jambannya tersebut.

Menurut Syamsul, Ketua II PK-41 Tim Menyapa Indonesia di dukuh Sebatang menjelaskan bahwa sekarang ini masih banyak program pemberdayaan masyarakat yang belum maksimal dalam membentuk kemandirian masyarakat. Pada pelaksanaannya masih belum mengikutsertakan peran aktif dari masyarakat sehingga kurang adanya rasa memiliki terhadap program tersebut. Maka menurutnya program Arisan Jamban di dukuh Sebatang merupakan cara yang efektif untuk mengatasi permasalahan sosial di dukuh tersebut.

"Banyaknya program pemberdayaan membangun pola pikir warga untuk selalu berpangku tangan terhadap bantuan yang datang. Melihat kondisi tersebut, Menyapa Indonesia menawarkan program arisan jamban. Di mana, warga ikut berperan aktif dalam pelaksaan program. Peran warga dapat dilihat dari penyerahan dana sebesar $30 \%$ dari total biaya yang dikeluarkan. Arisan jamban dilaksanakan melalui sistem sukarela. "Sistem sukarela tidak hanya diterapkan untuk nominal uang yang dikumpulkan. Namun, sistem sukarela juga diterapkan untuk waktu pengumpulannya." (Syamsul, 2016) 
Published December 2019

EKONOMIKAWAN : Jurnal IImu Ekonomi dan Studi Pembangunan

ISSN : 1693-7600 (Print), ISSN : 2598-0157 (Online), http://jurnal.umsu.ac.id/indexphp/ekawan

\section{Pencapaian Tujuan Program}

Hasil dari program ini yaitu pembangunan jamban yang telah direalisasi telah melampaui target sebanyak 58 jamban dari target awal yang hanya sebanyak 56 jamban. Hal ini salah satunya karena adanya bantuan berupa sumbangan para donatur di situs kitabisa.com sehingga dana yang terkumpul sebanyak Rp 17.986.600,- yang digunakan sebagai sumber biaya tambahan program arisan jamban. Adapun biaya total yang dikeluarkan untuk program tersebut yaitu sejumlah Rp 63.080.000,-. Setelah pembangunan jamban tersebut, program ini terus berlanjut melalui kegiatan monitoring dan evaluasi setiap enam bulan sekali, serta memastikan bahwa program kader penyuluh kesehatan berjalan secara efektif, serta pengadaan air bersih yang memenuhi standar kesehatan juga dapat dialirkan ke dukuh Sebatang agar mencapai kualitas kehidupan yang lebih baik.

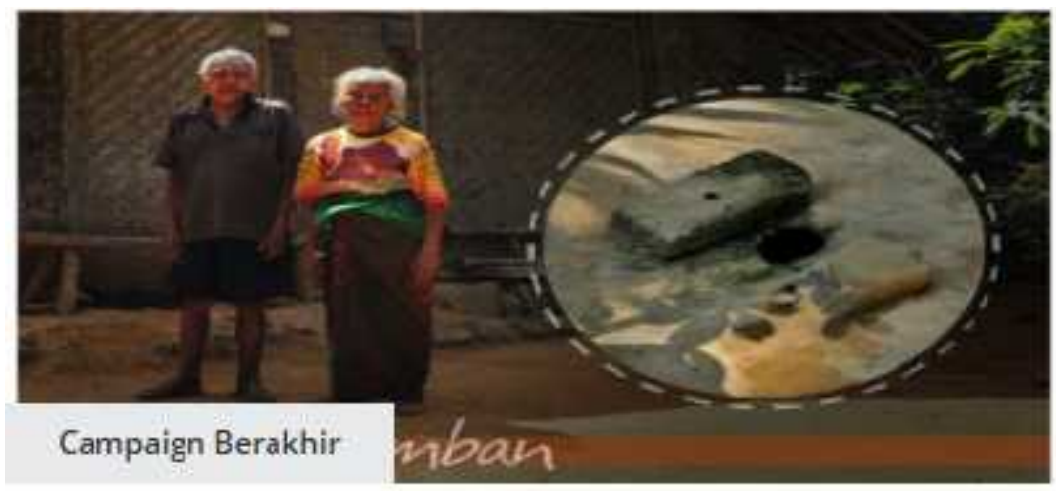

\section{Arisan Jamban: Bangun 56 Jamban di Dukuh Sebatang}

Menyapa Indonesia PK-41: ...

$\begin{array}{lr}\text { Tercumpul } & \text { Sisa hari } \\ \text { Rp } 18.986 .600 & \text { SELESAl }\end{array}$

Sumber : https://kitabisa.com/campaign/arisanjamban (Diakses pada 10 Oktober 2019)

Gambar 3. Donasi Arisan Jamban di situs kitabisa.com

Seperti yang diungkapkan oleh Triyono, warga dukuh Sebatang bahwa program arisan jamban ini bagi warga dukuh Sebatang dapat dirasakan manfaatnya dan adanya sosialisasi serta penelitian mengenai jamban cemplung membuat warga sadar akan bahaya jika harus $\mathrm{BAB}$ di jamban yang tidak sehat tersebut. Triyono menambahkan program arisan jamban ini juga mendapat dukungan warga sepenuhnya. Warga mulai sadar akan bahaya "Jamban Cemplung". Terlebih sebelum dijalankan program ini ada penelitian yang dilakukan dari akademisi. 


\section{Published December 2019}

EKONOMIKAWAN : Jurnal IImu Ekonomi dan Studi Pembangunan

ISSN : $1693-7600$ (Print), ISSN : 2598-0157 (Online), http://jurnal.umsu.ac.id/indexphplekawan

Sebelum memiliki jaman yang sesuai dengan kriteria jamban sehat, warga dukuh Sebatang masih menggunakan jamban yang hanya melobangi tanah dan menggunakan bilah kayu di sisi pinggirnya, kemudian di lubang itulah kotoran dibuang atau dicemplungkan. Warga pun memberi nama jamban tersebut sebagai jamban cemplung. Jamban cemplung ini pada dasarnya memiliki banyak kerugian dan rawan menyebabkan penyakit sebab jamban cemplung ini tidak memenuhi standar kesehatan yang ditetapkan oleh departemen kesehatan Republik Indonesia. Hal tersebut tentunya beresiko menimbulkan penyakit sebab bibit nyamuk dan hewan-hewan lain yang dapat menimbulkan masalah kesehatan dapat berkembang di lubang jaman cemplung itu, dan dapat membahayakan kesehatan terutama bagi anak-anak dan juga orang tua atau lanjut usia. Resiko lainnya yaitu apabila kayu rapuh, maka akan membahayakan penggunanya karena dapat terjatuh ke lubang jamban cemplung tersebut. Selain itu penggunaan jamban cemplung ini dapat mencemari lingkungan sebab kotoran di jamban tesebut dapat mencemari tanah dan air di sekitarnya dan tentunya dapat meningkatkan risiko penyakit akibat lingkungan yang tidak sehat.

Adapun syarat jamban sehat menurut Depkes RI (1985) yaitu :

a. Tidak mencemari sumber air minum (letak atau jarak antara sumber air dan lubang penampungan jamban minimal 10 meter)

b. Tidak berbau dan kotoran tidak dapat dijamah oleh serangga maupun tikus

c. Air seni, maupun air pembersih kotoran tidak mencemari tanah di sekitarnya

d. Mudah dibersihkan aman digunakan sehingga akan lebih baik dibangun dengan bahan-bahan yang kuat dan tahan lama

e. Dilengkapi dinding yang kedap air serta berwarna terang dan dilengkapi atap pelindung

f. Adanya penerangan dan ventilasi yang memadai

g. Terbuat dari lantai yang kedap air dan luas ruangannya memadai

h. Tersedia air, sabun,alat pembersih

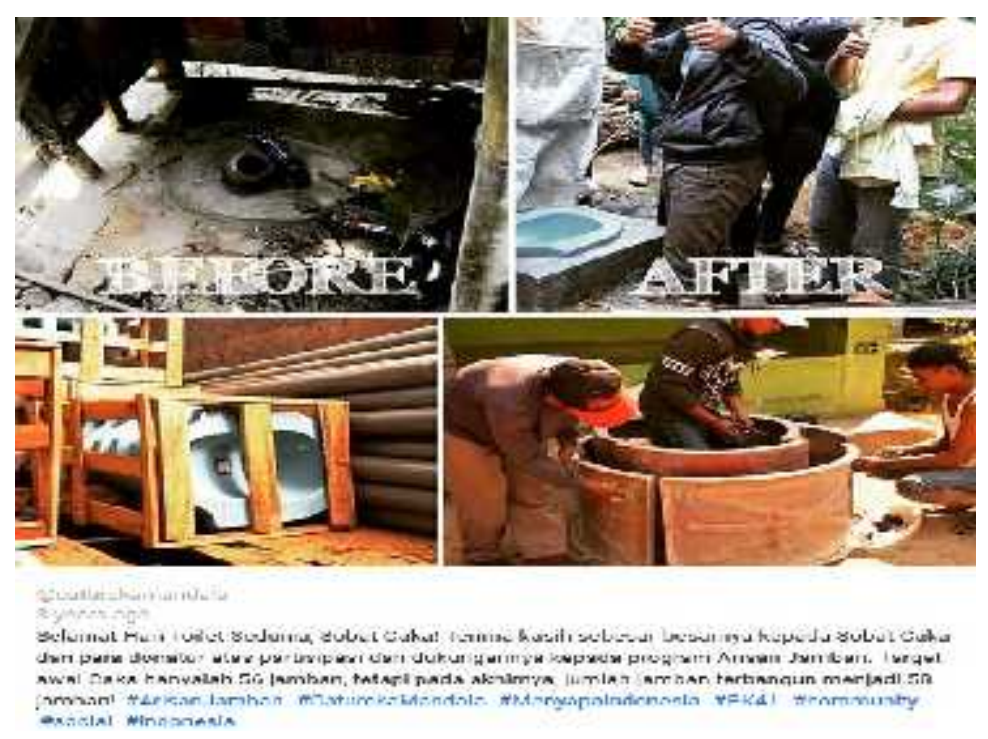

Sumber : http://picpanzee.com/caturekamandala (Diakses pada 10 Oktober 2019)

Gambar 5. Pembangunan Jamban di dukuh Sebatang 
Hal ini membuktikan bahwa jamban cemplung yang digunakan oleh warga di dukuh Sebatang tersebut belum memenuhi persyaratan-persyaratan jamban sehat yang telah disebutkan sebelumnya. Jamban sehat memrupakan kebutuhan yang penting bagi masyarakat sebab dengan terpenuhinya kebutuhan terhadap membuang kotoran yang benar dan tepat maka masyarakat dapat terhindar dari berbagai macam penyakit menular dan berbahaya akibat buruknya sanitasi kesehatan khususnya terkait jamban atau buang air besar.

\section{SIMPULAN}

Hasil dari penelitian mengenai pemberdayaan masyarakat program Arisan Jamban di dukuh Sebatang yaitu digunakannya prinsip-prinsip community development diantaranya analisa kebutuhan komunitas, dirumuskan tujuan, sasaran jangka panjang, sosialisasi program dan partisipasi masyarakat. Melalui program Arisan Jamban masyarakat dapat berperan aktif dalam membangun dan memelihara fasilitas kesehatan berupa jamban yang sehat sehingga kualitas kesehatan masyarakat di dukuh Sebatang semakin mengalami perbaikan dan menuju kemandirian.

Program Arisan Jamban ini telah berlangsung dan tahun 2016 berada di tahap monitoring dan evaluasi. Masyarakat secara swadaya memelihara jamban yang sehat karena mereka telah berpartisipasi aktif untuk urunan menggalang dana sehingga terbentuk rasa memiliki terhadap fasilitas kesehatan tersebut.

\section{DAFTAR PUSTAKA}

\section{Buku :}

Ife, Jim. 2008. Alternatif Pengembangan Masyarakat di Era Globalisasi: Community Development. Yogyakarta: Pustaka Pelajar.

Jefkins, Frank dan Daniel Yadin. 2003. Public Relations. Jakarta. Erlangga

Kartini, Dwi. 2009. Corporate Social Responsibility : Transformasi Konsep Sustainability Management dan Implementasi di Indonesia. Bandung : PT Refika Aditama.

Kriyantono, Rachmat. 2009. Teknik Praktis Riset Komunikasi. Jakarta. Kencana Prenada Media Group

Phillips, Rhonda and Robert H. Pittman. 2008. An Introduction to Community Development. USA. The Taylor \& Francis e-Library.

Rahman, Reza. 2009. Corporate Social Responsibility: Antara Teori dan Kenyataan. Yogyakarta: Media Pressindo

Ruslan, Rosady. 2006. Metode Penelitian Public Relations dan Komunikasi. Jakarta : PT Raja Grafindo Persada

Zubaedi. 2013. Pengembangan Masyarakat ; Wacana \& Praktik. Jakarta. Kencana Prenada Media Group.

Jurnal :

Endang Sutisna Sulaeman, Ravik Karsidi, Bhisma Murti, Drajat Tri Kartono, Waryana, Rifai Hartanto. 2012. Model Pemberdayaan Masyarakat Bidang Kesehatan, Studi Program Desa Siaga.

Saputro, Nurantono Setyo. Dampak Kegiatan CSR PT. TELKOM Terhadap Kemampuan Masyarakar dalam Mengakses Sumber Daya di Kawasan Punclut. Jurnal Perencanaan Wilayah dan Kota, Vol. 21 No. 2, Agustus 2010, hlm. 129 - 146 berbahasa Indonesia. 
EKONOMIKAWAN : Jurnal Ilmu Ekonomi dan Studi Pembangunan

ISSN : 1693-7600 (Print), ISSN : 2598-0157 (Online), http://jurnal.umsu.ac.id/indexphp/ekawan

Triyono, Agus. Pemberdayaan Masyarakat Melalui Community Development Program Posdaya (Pos Pemberdayaan Keluarga.) Prodi Ilmu Komunikasi Universitas Muhammadiyah Surakarta (KomuniTi, Vol. VI, No. 2 September 2014)

\section{Internet :}

http://menyapa-indonesia.com/category/gerakan/ (diakses pada 13 Maret 2016 Pukul 16.00)

https://kitabisa.com/arisanjamban (diakses pada 13 Maret 2016 Pukul 15.00)

http://kokap.kulonprogokab.go.id (diakses pada tanggal 11 Mei 2016 Pukul 12:59)

http://caturekamandala.esy.es/ (diakses pada 30 Mei 2016)

http://picpanzee.com/caturekamandala (Diakses pada 10 Oktober 2019)

https://kitabisa.com/campaign/arisanjamban (Diakses pada 10 Oktober 2019)

https://twitter.com/sapasebatang/status/629617746087559168 (diakses pada 10 Oktober 2019) 